\title{
Recortando Antonio Candido
}

\author{
Letícia Malard*
}

\section{RESUMO}

Lembranças pessoais e afetivas de Antonio Candido e de seu discípulo Alfredo Bosi em episódios da vida acadêmica na Universidade Federal de Minas Gerais (UFMG), seguidas da abordagem dos sete textos da autoria de Candido, publicados em 1993, no livro Recortes, porém inéditos até aquela data, comentando-os em sua contextualidade com o objetivo de detectar no crítico um discurso e/ou uma temática diferente daqueles pelos quais foi e é mais conhecido e estudado na academia: o resenhista de resenha literária, o defensor da integração literária da América Latina, o literato memorialista, o crítico genético-comparatista e o cidadão indignado com a violência e a censura.

Palavras-chave: Candido. Recortes. Inéditos. UFMG. Literato.

* Letícia Malard é professora emérita de Literatura Brasileira da Universidade Federal de Minas Gerais (UFMG) e doutora em Literatura Brasileira. Entre seus livros publicados, citam-se Literatura e dissidência política (2006) e o romance Divina Dama, (2013), pela Editora UFMG. 


\section{Selecting Antonio Candido}

\section{ABSTRACT}

Personal and affective memories of Antonio Candido and his disciple Alfredo Bosi in episodes of their academic life at the Universidade Federal de Minas Gerais (UFMG), followed by an examination of the seven texts authored and published by Candido in 1993, in the book Recortes, still unpublished then, with a comment about their context with the objective of detecting in the critic a different discourse and/or theme from those for which he was and is best known and studied in academia: the reviewer of literary reviews, the defender of the literary integration in Latin America, the memoir writer, the genetic-comparatist critic and the citizen indignant at violence and censorship.

Keywords: Candido. Selections. Unpublished. UFMG. Writer. 
Se a literatura se separa da errância banal da letra, ela só pode se ultrapassar - se suprimir - em uma estética generalizada que dá ritmo ao movimento da comunidade nova, das sementeiras e das festas do futuro. (RANCIÈRE, 1995, p. 16.)

Muito se tem escrito sobre Antonio Candido de Mello e Souza, o rei dos nossos estudos literários. Porém tenho a impressão de que, quanto mais se escreve, mais se tem a escrever sobre ele. Isso porque foi um estudioso da Literatura e das Ciências Sociais de qualidade inigualável na vida universitária brasileira, e de fácil comprovação: certa vez, presenciei uma conversa entre membros da Academia Brasileira de Letras, a propósito de candidatos que gostariam de entrar para ela, mas não queriam seguir o ritual, pedindo votos. Então, um acadêmico da diretoria disse a outro: "Meu amigo, isso só é possível no caso do Antonio Candido. Ele é o único que, se quiser, poderá entrar sem pedir, tal como a Irene entrando no céu, do acadêmico Manuel Bandeira”.

Entretanto, o nosso famoso carioca de nascimento e radicado em São Paulo jamais almejou a Academia Brasileira de Letras ou qualquer outra. Não por desprezo nem desfeita à Instituição, mas por entender que tal láurea não fazia parte de seus projetos pessoais. Foi o que me disse. E mais: como todo homem bom de família mineira, era desconfiado de si e dos outros. A saudade me faz registrar agora esse recorte psicológico do mestre querido, antes de entrar em seu Recortes. Numa carta a mim, de 17 de abril de 2014, começa dizendo que está "ficando um quase centenário muito relapso, que no entanto ainda se alegra com as coisas propícias [...]." (CANDIDO, 2014, p.1).

Imagina se alguém vai reclamar de relapsitude - ainda que existisse - de uma pessoa com 96 anos em plena lucidez! "Coisas propícias", no caso, eram documentos relativos a seu bisavô 
e tio-bisavô, atos de nomeação que localizei, por acaso, numa pesquisa sobre Educação no século XIX, no Arquivo Público Mineiro, cujas cópias lhe mandei. Ele, sempre admirador de genealogias, não tinha informações sobre aqueles papéis de seus antepassados e se alegrava em obtê-los, acrescentando: "Graças a você, incorporei um documento à história obscura de uma obscura família que veio de Lavras para a fronteira de São Paulo nos anos de 1840. Muito obrigado." (CANDIDO, 2014, p.1). Hoje não é preciso lembrar os frutos intelectuais que brotaram dessa árvore genealógica nada obscura: o pai Aristides, seus filhos Antonio Candido e Roberto, a neta Laura, etc., etc. Cito os que conheço de casos e de livros.

Creio que o cúmulo da desconfiança atesta outra carta, de 9 de dezembro de 1984, vinte anos antes da anterior, às vésperas do meu concurso para professora titular da Universidade Federal de Minas Gerais. Somente dias antes ficou sabendo que eu era candidata. Na carta lamenta não participar da banca examinadora, devido à forma como foi convidado para ela, forma que o levou a recusar o convite: mandaram-lhe um ofício onde deveria assinalar embaixo "aceitação" ou "recusa", e devolver à Faculdade. Relata ele:

Ao contrário de qualquer norma que tenho visto seguida em minha longa carreira, inclusive pela sua Faculdade, não se informava sobre data, candidato, membros da comissão, nem se fazia a clássica consulta prévia, sem falar no estranho critério de pedir devolução do ofício com a simples menção referida. Pensei tratarse dum meio de fazer sentir que, apesar do voto da Congregação, a minha presença não era desejada; por isso, atendendo ao drástico pedido, anotei em baixo a segunda alternativa e devolvi. (CANDIDO, 1984, p.1).

Antes do concurso, não tive conhecimento - claro - da correspondência que lhe fora enviada, mas apenas da sua recusa, 
e me perguntava, aflita: o querido professor de todos nós, para alguns presencial, para outros através da escrita, já teria tido notícia da minha tese e via defeitos irreparáveis nela? Entre não comparecer e reprovar, preferia a primeira alternativa? Afinal, o nosso professor direto ou indireto, tido como um examinador criterioso e finíssimo, não quereria meter-se em confusão na UFMG, cujo catedrático da matéria tinha sido o Wilton Cardoso, meu companheiro e seu amigo?

A situação só se esclareceu após o concurso: a inexperiência discursiva da funcionária que redigiu o Ofício. A direção assinou-o sem ler, pois é matematicamente impossível a um gestor conferir, palavra por palavra, todos os papéis encaminhados pelos assessores e em que a burocracia exige sua assinatura. A consequência foi o desconfiado examinador achar que a Congregação o indicara, mas para desgosto de alguma candidatura ao concurso...

Aliás, já que estamos no campo das lembranças acadêmicas, acho oportuno, no atual contexto político, abrir parênteses para evocar - dessa vez, nas trevas do Golpe Militar de 1964 - uma situação semelhante vivida por mim em 1972, com Alfredo Bosi, discípulo querido de Candido, na banca do meu doutorado. Sua arguição tratou apenas dos defeitos da tese, e ainda assim me aprovou com boa nota. Na época havia notas na defesa. Confesso que não entendia o porquê de generosa aprovação não bater com a severa arguição. Tempos depois, o Bosi me contou que o presidente da banca lhe dissera, em off, que ele tinha o tempo liberado, mas, a certa altura, fora surpreendido com o aviso de que o tempo estava esgotado. $\mathrm{O}$ arguidor achou estranho, mas obedeceu; nem sequer tinha entrado nas qualidades da tese disse ele. 
O que aconteceu, de fato, foi a chegada, à mesa, desta notícia secreta: a Polícia Federal estava pronta para intervir na sessão da defesa da tese. Segundo as forças da repressão, ela era sobre um escritor e um livro comunista [Graciliano Ramos Vidas secas], com Introdução em que Mao Tsé Tung era citado com simpatia, e apresentada por uma famigerada professora de esquerda. Então, o presidente da banca quis acelerar o processo antes da provável invasão ao auditório - fato corriqueiro na Ditadura - que só não aconteceu por negociações do reitor. Boa parte dos jovens de hoje - sobretudo os que vão às ruas pedir intervenção militar - não têm a menor ideia de como as coisas se davam. Narro esse episódio como um sinal de alerta.

Fechando o parêntese: recordando e recortando Antonio Candido, a intenção deste ensaio é fazer uma visita aos textos então inéditos, do livro Recortes (CANDIDO, 1993). Segundo a Orelha esquerda, "É o livro mais diverso que o autor já publicou, formando uma espécie de visão circular sobre o mundo, as pessoas, a literatura". Na "Explicação", o mestre declara que, de início, achava que tais textos deveriam permanecer inéditos ou apenas na publicação de origem, dado seu caráter circunstancial. Depois acabou reconhecendo que "muitas vezes um crítico se realiza bem nos escritos de circunstância, tanto quanto nos mais elaborados." (CANDIDO, 1993, p. 9).

Tenho para mim que os textos publicados nos livros posteriores, mesmo quando escritos ou falados em contextos de circunstancialidade, não guardam as características desses que o professor resolveu publicar somente aos 75 anos. Não nos apraz fazer conjecturas sobre o "esquecimento", ainda mais porque ele era uma personalidade à qual nunca lhe faltava bom espaço para publicar o que quisesse: só o nome do autor já trazia a chancela 
de qualidade. Contudo, é comum deparar com depoimentos bem-humorados de escritores, confessando ter esquecido papéis nas gavetas e encontrá-los somente quando vão arrumá-las na proximidade da "indesejada das gentes", como metaforizou Bandeira... de novo!

Os textos que serão visitados aqui não revelam o historiador da literatura brasileira e o crítico literário aos quais nós, os profissionais das Letras, estamos habituados, os quais vivemos citando em nossos trabalhos e indicando aos nossos alunos, orientandos e colegas. Também não repercutem o sociólogo das décadas de 1940-50, autor do clássico Os parceiros do Rio Bonito, nem o político dos anos 80, um dos fundadores do Partido dos Trabalhadores (PT). O Candido desses recortes circula por outras paragens, guardadas no fundo do baú até 1993, quando vieram à luz. São os que nos propomos a examinar, na crença de que pouco aparecem no conjunto significativo dos estudos sobre o Professor, o Crítico e o Político, bem como na quantidade imensa de citações de sua obra nos trabalhos acadêmicos, no Brasil e no exterior.

Nossa tese aqui é que, nesses inéditos até 1993, deparamos com, pelo menos, cinco Candidos: o crítico resenhando a resenha de outro crítico; o crítico-historiador literário preocupado com a integração cultural do Brasil na América Latina; o crítico comparatista-genético; o literato memorialista e o pensador da liberdade de expressão. Trata-se de Candidos diferentes, se comparados à quase totalidade de seus escritos, que ora dialogam com essa totalidade, ora nada têm a ver com ela. São ângulos do Crítico que ficaram na obscuridade, talvez esquecidos na gaveta, por culpa dele mesmo, ou para serem lembrados vez ou outra, necessitando de alguma revisão, algum acerto. Como as 
fronteiras do Crítico, do Professor e do Político são flutuantes, nem sempre é fácil limitá-las. Há casos em que os escritos não foram publicados porque o periódico ou o livro não saiu, por motivos inclusive de censura ditatorial. $\mathrm{O}$ autor, aborrecido ou indignado com o fato, abandonou o escrito para, quem sabe, um dia... Mas, penso que não perdem o "realizar-se bem", conforme se lê na mencionada "Explicação".

Em número de sete, os inéditos são, pela ordem no livro: "Acerca de André Gide" (parte de palestra em 1987); "Os brasileiros e a nossa América" (1989); "O olhar crítico de Ángel Rama" (s.d.); "Arnaldo" (1974.); "Censura-violência" (1979); "O barão" (s.d.); "Abecedários" (s.d.). Não especulamos sobre a data provável daqueles não datados porque não é nossa intenção trabalhar aqui com elementos cronológicos.

O primeiro texto, "Acerca de André Gide", é uma resenha do livro Anatomie d'André Gide (1972), de Roger Bastide. O sociólogo francês foi professor de Candido nos três anos do Curso de Sociologia da Universidade de São Paulo (USP), participou de sua banca de doutorado em Ciências Sociais, foi seu interlocutor. Em entrevista a Maria Lúcia Santana Braga, diz que essa interlocução foi definitiva para que ele se mudasse da Sociologia para a Literatura: o ex-aluno lembra que o prof. Bastide "Era um homem que cuidava muito da literatura. Era bom crítico literário. Ele era muito bom crítico literário." (BRAGA, 2000, p. 341). Essas relações explicam em parte o motivo da resenha do último livro - e de crítica literária - da vasta bibliografia de seu querido mestre sociólogo. Também era uma forma de homenagear o antigo professor, que morreria dois anos depois. Veja-se a seguir outra motivação.

O ex-aluno começa a resenha dizendo que Bastide não está interessado na obra de Gide como texto, "mas como experiência 
criadora, expressão de uma personalidade extremamente complexa, embora possuindo constantes, linhas principais que ele procura descobrir." (CANDIDO, 1993, p. 110). Lembre-se que o Prêmio Nobel genial, depressivo, homossexual assumido, proibido pela igreja católica e polêmico André Gide (18691951), autor de Corydon, ensaio onde combate o preconceito à homossexualidade, sempre angariou muitos admiradores por aqui.

O resenhista mostra que Bastide tem seus próprios conceitos de estruturalismo - diferentes daqueles vigentes à época, que sofriam o impacto da Linguística e que não receberam a aprovação nem do resenhador nem do resenhado. Estive presente à conferência do primeiro, no III Encontro Nacional de Professores de Literatura, na Pontifícia Universidade Católica do Rio de Janeiro (PUC-RJ), intitulada "Literatura-Sociologia" (1976), sobre o romance O cortiço, de Aluísio Azevedo. No evento, predominavam as abordagens estruturalistas, inclusive a de Affonso Romano de Sant'Anna sobre o mesmo romance. O enfoque de Candido destoava, o que levou Romano a publicar no ano seguinte o artigo "Curtição: 'O Cortiço' do Mestre Candido e o Meu" (SANT'ANNA, 1977, p. 213-235). No entendimento tanto de Bastide quanto de Candido, a crítica descritiva trabalha apenas a "matéria bruta", ficando de fora o significado. E concluem: na obra literária "o que interessa não é a estrutura da matéria, nem a estrutura do espírito, mas o processo dinâmico por meio do qual o espírito cria a matéria. Deste modo é possível chegar a sentir a beleza da matéria e a originalidade do criador." (CANDIDO, 1993, p. 111).

Daí - continua o resenhista - o intelectual francês estudar Gide através de temas definidos: o furto, a montanha, o olho 
furado, o ato gratuito, o filho de pai incógnito e a propriedade. Estes são manifestados e regidos segundo esquemas diretores, em número de quatro: alternância, desdobramento, multiplicação e simbolismo. O estudo de Bastide permite compreender a significação da obra criada e estruturada através deles, para dar conta de que a obra e a personalidade de Gide são inseparáveis.

Tanto Anatomie d'André Gide quanto "Acerca de André Gide" são também um confronto com o estruturalismo dos anos 70, período em que o livro de Bastide foi publicado na França - pátria de estruturalistas de diversa natureza -, porém não rezando na mesma cartilha em que eles. O procedimento de Bastide, aprovado por Candido, na conjugação de temas com esquemas, tentava superar os modelos estruturalistas que não conseguiam ultrapassar o descritivismo linguístico dos textos. Se a data da resenha, 1987, está correta, Candido já tinha um bom distanciamento da onda estruturalista para lhe fazer reparos, não se tratando de autocrítica porque nunca mergulhou naquele mar. Assim, pode-se afirmar que um Candido estruturalista formal jamais existiu.

A título de curiosidade, vale comparar essa resenha com a de Luís Martins (1907-1981), sobre o mesmo livro de Bastide, porém sob outra perspectiva, publicada ainda na década áurea do Estruturalismo, mas também não aderente a ele:

Arigor, o que Bastide analisa (ou disseca) é aquela "moral da ambiguidade" que seria a marca registrada de Gide mas para refutá-la, da maneira mais lúcida e inteligente possível. [...] A obra é vasta partitura musical, onde os temas não se cristalizam, se transformam uns nos outros, continuando, não obstante, sempre os mesmos." (MARTINS, 1978, p. 122-123, grifo nosso).

Entramos aqui, apenas en passant, num campo que merece pesquisas mais aprofundadas: os conhecimentos profissionais do 
crítico em geral na determinação analisadora da obra. No caso dos dois sociólogos, a determinação é positiva: a importância dos temas e esquemas conjugados para a totalidade de Gide, como escritor e obra. No caso de Martins - que nem exercia a profissão de músico - a obra de Gide é "vasta partitura musical".

O objetivo do segundo texto, "Os brasileiros e a nossa América", é revelar a presença da América Latina na literatura e no pensamento do Brasil, e como este se preocupa mais com a América Hispânica do que o oposto. Primeiramente, Candido faz uma listagem de nossas primeiras obras literárias em que o sentimento dessa América comparece: O Uraguai, de Basílio da Gama (1769), Ataualpa (peça de teatro perdida), de José da Natividade Saldanha, Colombo (1866), de Manuel de Araújo Porto Alegre, O Guesa errante (1866), de Sousândrade. Mas o que interessa ao crítico é o período entre 1880 e 1920, uma vez que foi aí que se sistematizou uma melhor reflexão sobre o assunto - com Joaquim Nabuco, Sílvio Romero, Eduardo Prado, Oliveira Lima e Manoel Bonfim.

Candido vai comentar as obras dessas personalidades, pertinentes à matéria. Revela como Nabuco critica o aristocratismo do estadista chileno Balmaceda, com suas ideias defensoras da democracia das elites como solução. Eduardo Prado, preconceituoso contra a América Latina e antiestadunidense, prega o imperialismo europeu no lugar do norte-americano. Já Oliveira Lima, monarquista porém o melhor conhecedor do assunto, achava que o predomínio dos Estados Unidos deveria ser enfrentado não por tratados e declarações, mas pelo real progresso da região. $\mathrm{Na}$ área da crítica literária, destaca José Veríssimo, que publicou artigos sobre escritores latino-americanos, mas, pessimista, achava que a miséria, a ignorância e a violência só poderiam ser combatidas por uma pequena elite civilizada e instruída. 
A Revista Americana (1909-1919), de poesia, narrativa e ensaio, iniciativa do chanceler Rio Branco, era publicada em português e espanhol. A participação brasileira foi maior e de melhor qualidade literária, inclusive a de Euclides da Cunha, contrário ao pan-americanismo, por arriscar-se a fazer o jogo do imperialismo norte-americano. O periódico construiu "um esforço notável de aproximação continental, a começar pelo bilinguismo e sem esquecer a equanimidade com que eram publicados artigos severos sobre o Brasil". (CANDIDO, 1993, p. 135)

Contudo, continua Candido, o nome de maior destaque é Manoel Bonfim, cujo livro A América Latina (1905), ficou esquecido. Apesar das limitações bebidas em Rocha Pombo, historiador problemático, "apresenta uma visão profunda e inovadora". O crítico retoma-o em seu clássico ensaio "Literatura e subdesenvolvimento" (1973), um dos mais lidos e estudados de seu acervo. Vale a pena transcrever a leitura de Chiappini sobre o ensaio que causou alvoroço nos porões da ditadura militar e levou à censura a revista que o publicara. Subjacentemente, o autor não limita o período pós-1950, jogando o governo militar na fogueira da agudização do subdesenvolvimento:

Em "Literatura e subdesenvolvimento", Antonio Candido parte da ideia de país subdesenvolvido contrapondo-a à antiga ideia de país novo e estabelecendo uma cronologia. Antes de 1920, o país seria visto como novo e a sua literatura seria portadora da visão pitoresca, grandiosa, grandiloquente, compensando o atraso pela grandeza da natureza e uma esperança divina, como a que se expressa no hino nacional brasileiro, cuja letra descreve um Brasil gigante e um povo esperançoso. Em 1930, já apareceria uma préconsciência do subdesenvolvimento, perceptível no romance regionalista de denúncia e análise social. E, a 
partir de 1950, com Guimarães Rosa, isso se agudizaria numa consciência plena desse subdesenvolvimento. (CHIAPPINI, 2011, p. 20).

Afirmando que Bonfim explica nosso atraso pelo "prolongamento do estatuto colonial, traduzido na persistência das oligarquias e no imperialismo estrangeiro" (CANDIDO, 1973, p. 13), o crítico passa a sumariar o livro. Nesse resumo, escrevendo no clima da nova Constituição Brasileira sobre a ideia talvez a mais importante de Bonfim, acaba por afirmar, nas entrelinhas, que nossa América quase nada mudara em mais de oitenta anos, dado seu "conservantismo visceral". Candido adapta o livro de Bonfim de 1905 para 1989, e eu o adapto para 2019. Cito Candido:

Arraigado na alma e na afetividade de cada um, ele [o conservantismo] atua a despeito das convicções aparentes: Estas podem ser liberais e até radicais, exprimindo-se por meio de leis e discursos avançados, que na verdade servem para mascarar o essencial, isto é, o mecanismo de permanência das oligarquias baseadas na espoliação econômica das massas trabalhadoras, mediante uma capacidade excepcional de acomodação e transigência, do tipo "mudar para continuar." (CANDIDO, 1993, p. 138.).

O terceiro ensaio, "O olhar crítico de Ángel Rama", dá continuidade à temática do conhecimento, do intercâmbio e da integração das nações latino-americanas - mais especificamente no que tange à Literatura -, empenho do uruguaio Ángel Rama (1926-1983). Candido enumera os problemas que Rama enfrentou em suas reflexões: a posição do escritor e sua atitude política; a questão das literaturas nacionais ante uma possível integração da literatura subcontinental, e a dialética 
do processo cultural entre as condições dos estados latinoamericanos versus as sugestões literárias dos estados centrais.

A análise de Candido privilegia o livro La generación crítica (1972), sobre essas questões no Uruguai entre 1940-1960, onde a participação dos intelectuais pequeno-burgueses se deu pela imaginação criadora e a consciência crítica, manifestadas através do ensaio, da narrativa, da poesia, do teatro e da crítica literária. Aqui Candido retorna à categoria "imaginação criadora", que já o entusiasmara no ensaio gidiano de Bastide, como vimos. Ainda que sendo um crítico literário oriundo da Sociologia, sua visão da Literatura articulada com a Sociedade publicou livro com título articulador - incluía obrigatoriamente elementos estéticos.

Alguns pressupostos teóricos de Rama para a literatura hispano-americana esbarram no problema da língua, implicando a dicotomia América Hispânica/Brasil - observa Candido. Entretanto, diz ele que mais tarde o uruguaio supera essa barreira, ao substituir "hispano-americana" por "latino-americana", a partir da produção literária iniciada em 1910. Assim teria sido criado na América Latina "um único sistema literário comum", sendo o Brasil sua parte integrante e passando a língua para segundo plano. Candido se apresenta como um entusiasta dessa unidade literária subcontinental - que nos parece utópica, diga-se de passagem - e talvez também se iludiu, mais tarde, com a criação do Mercado Comum do Sul (Mercosul), em 1991, na esperança de que as regras traçadas para o Mercado propriamente dito poderiam valer também para a Literatura. Hoje, se consultamos a estrutura organizacional do órgão, nem mesmo a palavra "literatura" comparece (MERCOSUL, 2019). E, na página em Português da Wikipédia sobre a instituição, no 
item "Cultura", a única informação existente é a adoção de três línguas oficiais no Organismo: Português, Espanhol e Guarani. (MERCADO COMUM DO SUL, 2019).

E mais: na XLV Reunião dos Ministros de Cultura do Mercosul, a 26 de junho de 20199, em Buenos Aires, o ministro brasileiro da Cultura Osmar Terra menciona em sua fala diversas categorias culturais, exceto a Literatura. O mesmo se observa na intervenção do secretário argentino (45 Reunión de Ministros de Cultura / 45 ${ }^{\mathrm{a}}$ Reunião de Ministros da Cultura do Mercosul, 2019). Talvez aleguem que a Literatura tenha comparecido embutida em alguma categoria, mas com outro nome que desconheço, e mais de acordo com os novos tempos. E mais ainda: no momento em que escrevo (em 17 de julho de 2019), em tempo real acabo de ouvir o discurso de abertura do presidente da república brasileira e do Mercosul, na reunião de cúpula que se realiza na Argentina. Nenhuma palavra sobre Cultura, muito menos sobre Literatura. "Tempos estranhos..." e contrários às aspirações integracionistas de Antonio Candido.

$\mathrm{O}$ estudioso encerra o seu ensaio tecendo os maiores elogios a Rama e abordando o terceiro problema enfrentado pelo pensador: "a relação entre as influências dos países centrais e as necessidades expressivas próprias da América Latina" (CANDIDO, 1993, p. 146). A ideia vai desembocar na questão da vanguarda, cujos focos principais foram São Paulo e Buenos Aires, em dois modos: um, vinculação às vanguardas europeias, que serviam de modelo e estímulo para uma perspectiva universalista; o outro modo foi a penetração na realidade local, tendente ao realismo, que suscitará o regionalismo continuador do passado. $\mathrm{O}$ fenômeno gerou uma vanguarda dupla, pois não raro a renovação se exprimia através do regionalismo. 
O resultado foi Rama considerar o Macunaíma “a articulação mais feliz do sistema literário brasileiro" (CANDIDO, 1993, p. 146), para alegria de Candido e família, mais do que admiradores de Mário de Andrade. Conclui mostrando como o regionalismo funde esses dois modos conflitantes, ambos criação própria do universo literário latino-americano. Dessa forma se chega à solução mais adequada para o regionalismo de José María Arguedas, Juan Rulfo, García Márquez e Guimarães Rosa.

Vamos focalizar em conjunto os textos "Arnaldo" e "O barão", por um importante motivo: neles emerge um Candido completamente diverso dos demais, levando-nos a lamentar que ele não tenha dado sequência à empreitada, isto é, escrever textos com fortes características literárias. Seguramente alguém deve ter-lhe indagado sobre isso. Gostaria de saber a resposta, sobretudo porque teve um irmão escritor, segundo ele "um homem de grande talento, ao qual devo muitas sugestões que aproveitei em meu trabalho crítico." (CANDIDO, 2014, p. 2). Trata-se de Roberto de Mello e Souza (1921-2007), autor de cinco obras de ficção, entre elas Mina R, de cunho autobiográfico, pois tematiza suas experiências militares na Segunda Guerra Mundial.

"Arnaldo" é um perfil do amigo Arnaldo Pedroso d'Horta (1914-1973), graduado em Ciências Jurídicas e Sociais pela USP, professor, jornalista, militante político, artista plástico e crítico de Arte. Dirigiu o Museu de Arte Moderna de São Paulo e, junto com Candido, a Folha Socialista (ARNALDO PEDROSO D'HORTA, 2015). No escrito, Candido se mostra possuidor de um estilo literário sóbrio e elegante, capaz de desenhar a pessoa e a personalidade de Pedroso d'Horta com os melhores recursos no trabalho com a linguagem. Algum 
leitor pode desgostar do excessivo emprego de qualificativos.

Contudo, nessa plataforma de memória literária da amizade, a adjetivação se encaixa como uma luva. Arriscamos a afirmar que se pode sentir nessa expressividade um misto de imaginação criadora e realismo memorialista, uma evocação dos "perfis" ecianos em jogo com os contundentes retratos de Pedro Nava. A citação é propositadamente longa, para que se dê conta do também talentoso Candido em matéria de produção literária, à qual, infelizmente, pelo que se sabe, não deu andamento:

[Arnaldo] Era gregário, sendo solitário de modo visceral. Nunca fez uma confidência na vida, mas não podia passar um dia sem ver amigos. Falava pouco, mas exigia muita fala, muito riso em volta de si. Era áspero e quando calhava podia ser bruto, no entanto transbordava sempre de uma ternura que nadava em lágrimas nos seus olhos claros e salientes. Era um homem de amizades e era um homem de tarefas. Tendo muito de fanático, se afastou desde cedo das posições que erigiam o fanatismo em norma de conduta. O dele era um fanatismo da liberdade, uma paixão (rara) da responsabilidade, uma intransigência ríspida.

$[\ldots]$

Era preciso vê-lo numa reunião partidária, jogando lentamente as palavras como pedras, vermelho e espinhado, pedindo conta dos deslizes, algumas vezes meramente supostos pela sua vigilante desconfiança. E era preciso também passar os dias e as noites, duas, três, quatro, chefiando um setor de trabalho, controlando as tarefas, distribuindo material - paciente, cortante, incansável, bebendo uma cerveja e comendo um vago sanduíche, aferrado como maníaco tranquilo à tarefa, obrigação, ao que era preciso fazer, ao que pesa inelutável porque era um compromisso. Arnaldo custava a tomar as suas resoluções bovinas, mas quando as tomava, era isso. (CANDIDO, 1993, p. 194-195).

"O barão" é outro texto memorialista, sobre o austríaco Leopold Freiherr Ferdinand von Andrian zu Werburg) (1875- 
1951) - escritor e diplomata que Antonio conhecera aos vinte e três anos de idade, na casa de sua família em Poços de Caldas-MG. Em 1941 e aos sessenta e seis anos, o barão estava refugiado no Brasil e fora tratar-se de uma artrite naquela estância hidromineral. Candido trabalha as próprias lembranças de juventude através de três cartas que encontrou entre os papéis deixados pelo Dr. Aristides de Mello e Souza, médico e seu pai; duas cartas do barão a este, em Francês, que Candido traduz, e uma do Dr. Antônio Silva Mello, médico famoso do Rio de Janeiro, enviada ao Dr. Aristides, recomendando-lhe o austríaco. As três cartas são transcritas e comentadas pelo crítico.

Pouco se sabia daquele estrangeiro de grande cultura e finesse. Ficou hospedado em hotel, mas frequentava a casa da família Mello e Souza, narrando-lhe fatos interessantes, fazendo comentários bem-humorados sobre o País e dando respostas mais interessantes ainda às perguntas do curioso jovem. Somente após sua morte, anos mais tarde, foi que Candido se interessou por pesquisar sobre o barão, e verificou que ele fora uma personalidade cultural de certa importância na Áustria. Imprimindo ao texto uma literariedade similar à que se encontra em "Arnaldo", o autor se utiliza do expediente narrativo romanesco de apelar para cartas, a fim de montar a sua história. $\mathrm{O}$ início do último parágrafo remete ao não crítico literário, quer dizer, ao memorialista preocupado em simplesmente resgatar uma situação pitoresca de suas férias de antanho, colocando à margem tudo aquilo que poderia perturbá-la. Aí ele faz uma mixagem do seu próprio texto, literário (a figura enigmática do Barão, captada do passado), com o texto historiográfico de Carl Schorske, erudito (a figura real do Barão, lida no presente): 
No entanto, o que vive em mim não é a mensagem literária "fin-de-siècle" de um escritor que nunca li; nem o perfil do aristocrata circulando nas rodas culturais de Viena, como relata Schorske [Carl Emil Schorske, autor do livro Viena fin-de-siècle: Política e cultura - 1980]. É mesmo o velhinho franzino e quase entrevado que andava de arranco, sempre com o mesmo terno cinza, trazendo atravessada de um bolso a outro do colete a corrente do relógio carregada de miniaturas das suas condecorações; [...] (CANDIDO, 1993, p. 240).

O texto "Abecedários" encerra o livro Recortes, e de uma forma inusitada: o autor retorna à crítica literária em sentido estrito, dessa vez articulando comparativismo e geneticismo articulação rara no conjunto de sua obra. O título não remete a "Alfabetos", mas a uma espécie de composição poética cujo número de estrofes corresponde ao número das letras do alfabeto. A primeira palavra da primeira estrofe começa por A, a da segunda estrofe começa por B, e assim sucessivamente, até a letra $\mathrm{Z}$. Na literatura popular dos cantadores, hoje é mais conhecida como "ABC", e no geral procura desenhar fatos da vida de personalidades.

Nesse texto, Candido se propõe a deslindar uma polêmica: o ABC pautado em costumes, de tendência ético-religiosa, publicado no livro Compêndio narrativo do peregrino da América (1728), de Nuno Marques Pereira, em confronto com uma versão do mesmo $\mathrm{ABC}$, do século XIX, tido como composto pelo Coronel João José Carneiro de Mendonça, de Paracatu-MG, em poder dos descendentes que afirmavam ser o ABC originalmente da autoria do coronel. Geir Campos afirma que, para o cantador, vale "como verdadeira consagração o aparecimento de um ABC, sobre tal ou qual motivo." (CAMPOS, 1965 , p. 9). O coronel deveria ser um homem poderoso, a quem 
faltava pouco. Talvez, uma pequena glória nas Letras, para as quais não tinha pendor - donde o "plágio" de certo trecho de um livro popular à época.

Candido não informa sobre a motivação do seu ensaio, mas acredito que o tenham metido numa calça justa: especulo que, pelo fato de Carneiro de Mendonça ser uma família importante e tradicional no cenário político e cultural brasileiro, à qual pertenceu Bárbara Heliodora (não a musa de Alvarenga Peixoto, mas a erudita crítica de teatro, especialista em Shakespeare), algum de seus membros o procurara para dar uma sentença sobre a autoria. Apesar de ter produzido seu veredito críticoanalítico, o autor acaba por escrever também um "Abecedário" sobre o coronel envolvido na discussão autoral, ao traçar, depois de concluir sua análise, um esboço biográfico dele, em prosa. Caso minha especulação tenha pé e cabeça, estamos diante da inteligência de um crítico literário que fez do encomendante não um buscador de lã que saiu tosquiado, mas que saiu com uma manta para pouco frio. Antes de nos determos na questão, citemos a estrofe da letra $\mathrm{V}$, em ambas as versões, que estão, no livro, em duas colunas. Nossa intenção é apenas introduzir o leitor no clima do poema e suas respectivas versões. Versão de Nuno Marques Pereira:

\author{
Vivendo sempre ajustado, \\ Conforme a renda, ou despesa, \\ Gastar menos, é baixeza; \\ Gastar mais, será pecado. \\ (CANDIDO, 1993, p. 261)
}

Versão de João José Carneiro de Mendonça:

Viver, mas sempre ajustado

Conforme a renda a despesa, 
Gastar menos é baixeza,

Gastar de mais é pecado.

(CANDIDO, 1993, p. 261)

De primeira, Candido viu, só pelo confronto de datas, a impossibilidade de um texto, publicado em 1728, ter sido escrito em 1810, deixando decepcionada a família. Mas optou por sair - com finura e elegância, suas marcas registradas - pela tangente: teve a pachorra de fazer um belo e criterioso estudo comparativo de ambas as versões - a de Pereira e a do Coronel: vinte e uma quadras em redondilhas maiores para cada versão, transcrevendo-as e comparando-as, palavra por palavra. Mesmo concluindo definitivamente tratar-se da mesma obra, revela qualidades da reescrita, detecta diferenças provenientes de ideologias das épocas e, por fim, anexa à análise um estudo sobre o autor da versão B. Encontra, inclusive, justificativa para o texto de Marques Pereira ter figurado como do patriarca Carneiro de Mendonça: em conversas na família, certamente se referiam aos versos como "o $\mathrm{ABC}$ de meu pai", frase interpretada não como "o ABC que meu pai utilizava" - o que seria o correto - mas "o $\mathrm{ABC}$ de autoria do meu pai".

Parece que o superinteligente Antonio Candido conseguiu, sem falsear nem desdizer nada, colocar os pingos nos "is" numa polêmica sobre autoria, agradando a gregos e troianos: especialistas em crítica genética, literatura comparada e a descendência de Carneiro de Mendonça. Este ficou, de algum modo, com a consagração apontada por Geir Campos, pois o crítico provou que sua versão é tão válida quanto a do Peregrino da América. Isso, dedicando-se a um paciente trabalho nas respectivas especialidades. Creio ter sido uma tarefa até prazerosa para o mestre, que até lhe imprimiu um cunho de literariedade na conclusão: 
Hoje, passados mais de duzentos anos do nascimento, João José pode ser visto sob o aspecto de um velhote plácido, ao lado da mulher carrancuda, num belo grupo de família daguerreotipado no decênio de 1840 . Deixado para trás o seu sertão, com jagunços, tropelias e revoltas, ele parece mesmo um seguidor conformista do $\mathrm{ABC}$, que pode ter registrado em versão diversa ou, mais provavelmente, modificado para melhor. Mas não sou capaz de dizer, até novas informações. (CANDIDO, 1993, p. 266).

Finalmente chegamos ao último texto - "Censura-violência" - escrito para sair em um volume coletivo, em 1979, sobre a repressão no tempo da ditadura militar. O volume não saiu. É interessante a atualidade desse texto. Começo os comentários com uma citação do filósofo Renato Janine Ribeiro, na Folha de S. Paulo de ontem, 16 de julho de 2019:

Antonio Candido uma vez escreveu um manifesto dos docentes da USP criticando a "mediocridade irrequieta" que comandava a universidade. Um colega discordou: a mediocridade nunca é irrequieta! Mas Candido tinha razão. A mediocridade procede hoje, sem pudor, ao desmonte de nossas conquistas não só políticas e sociais, mas culturais e ambientais.

A irracionalidade vai a ponto de algumas dezenas de paratienses tentarem sabotar a Flip, que dá projeção e dinheiro para a cidade. Essa é a metáfora de um país que namora o suicídio. (RIBEIRO, 2019, p. A3.).

O título "Censura-violência" por si só já diz tudo. O crítico começa declarando que "A censura é uma forma eficaz e profunda de violência, e a violência se tornou em nosso tempo horizonte e limite." (CANDIDO, 1993, p. 204). Em seguida denuncia que seus agentes não a assumem, além de renegá-la e condená-la. Denuncia a mitologia histórica do Brasil pacífico e cordato, da violência "contrária à índole do nosso povo", e dá 
exemplos de como a nossa História é uma história de violência. A "clava forte" do hino acaba por ser também censura, porque pressiona a inteligência e a criatividade, ou seja, executa a censura.

Afirmando que a violência física e a mental são violência social, Candido, escrevendo isso há quarenta anos, parece ter escrito ontem, junto com Janine Ribeiro. Diz Candido:

Hoje, é espantoso ouvir e ler os pronunciamentos das autoridades de todos os níveis, que falam com veemência crescente que a miséria do povo é intolerável, que a concentração da riqueza deve ser mitigada, que a pobreza é um mal a ser urgentemente superado - não raro com estatísticas demonstrativas. [...] e é espantoso porque isso é dito, mas quem diz faz tudo para que as coisas fiquem como estão, e para que os que querem mudar sejam enquadrados pela força." (CANDIDO, 1993, p. 205).

Sua tese é a de que o casamento da censura com a violência tem o objetivo de manter a ideologia do abafa da verdade - que são as desigualdades. A propósito, o crítico entra com a questão da censura à revista Argumento, e a violência do caso "Vladimir Herzog", morto nas dependências do famigerado DOI-CODI de São Paulo - acontecimentos icônicos dos anos 1970. O texto é um apelo veemente aos intelectuais para enfrentar a violência, bem como reagir e lutar contra a censura, que é a "mordaça aviltante" da violência.

Assim, se estivesse vivo hoje, creio que o Mestre não se espantaria com a sabotagem à Flip, com o cerco ao barco que levou o jornalista Greenwald - o qual trouxe à baila os desmandos da famigerada Operação Lava Jato - ao local de sua apresentação. Ele, o Mestre Candido, já vivera e convivera com isso, a bem da verdade desde a ditadura Vargas, quando 
dirigia a Folha Socialista, passando pela ditadura militar - que decretou a morte da revista Argumento - e desembarcando no Golpe Parlamentar de 2014, cujas consequências não chegou a presenciar. Afinal, a mediocridade - quieta ou irrequieta, pouco importa - sem excessivas ilusões será superada ou suprimida pelas "festas do futuro" a que se refere Jacques Rancière. É no que acredito.

\section{Referências}

$45^{\circ}$ Reunión de Ministros de Cultura / $45^{\circ}$ Reunião de Ministros da Cultura do Mercosul. Montevidéu: Ed. MERCOSUL, 1 jul. 2019. 1 Vídeo (2 min.). Publicado por Canal oficial no YouTube do MERCOSUL. Disponível em: <https://www.mercosur.int/ ministros-de-cultura-del-mercosur-trabajando-juntos-por-laintegracion-regional/>. Acesso em: 13 jul. 2019.

ARNALDO PEDROSO D'HORTA. Amigos correspondentes. 2015. Disponível em: $<$ https://www.arnaldopedrosodhorta.com. br/blank-c9ym>. Acesso em: 13 jul. 2019.

BRAGA, Maria Lúcia Santana. A recepção do pensamento de Roger Bastide no Brasil. Sociedade e Estado, v.15, n. 2, p. 331360, dez. 2000.

CAMPOS, Geir. Pequeno dicionário de arte poética. Rio de Janeiro: Edições de Ouro, 1965.

CANDIDO, Antonio. [Correspondência]. Destinatário: Letícia Malard. São Paulo, 9 dez. 1984. Carta Inédita.

CANDIDO, Antonio. [Correspondência]. Destinatário: Letícia Malard. São Paulo, 17 abr. 2014. Carta Inédita.

CANDIDO, Antonio. Literatura e subdesenvolvimento. Argumento, a.1, n. 1, p. 6-24, out. 1973. 
CANDIDO, Antonio. Recortes. São Paulo: Companhia das Letras, 1993.

CHIAPPINI, Lígia. Do subdesenvolvimento à interdependência: as duas pontas do nó. Revista do Instituto de Estudos Brasileiros (IEB), n. 53, p. 13-30, mar.-set. 2011.

MARTINS, Luís. Anatomia de André Gide. Revista do Instituto de Estudos Brasileiros (IEB), n. 20, p. 122-125, 1978.

MERCADO COMUM DO SUL. Cultura. Disponível em: $\quad<$ https://pt.wikipedia.org/wiki/Mercado_Comum_do_ Sul\#Cultura $>$. Acesso em: 13 jul. 2019.

MERCOSUL. Organograma. Disponível em: <https:// pt.scribd.com/doc/23839444/organograma-Mercosul>. Acesso em: 16 jul. 2019.

RANCIÈRE, Jacques. Políticas da escrita. Rio de Janeiro: Ed. 34, 1995.

RIBEIRO, Renato Janine. A Flip e o fascismo. Folha de S. Paulo, São Paulo, 16 jul. 2019.

SANT'ANNA, Affonso Romano de. Análise estrutural de romances brasileiros. Rio de Janeiro: Eldorado Tijuca, 1977. 